\title{
Physicochemical and microbiological evaluation of natural mineral water produced in Mato Grosso State, Brazil
}

\author{
Ilza Conceição Tomaselli Ribeiro (iD) 1*, Adriana Paiva de Oliveira (iD 1, Andressa de \\ Souza David (iD) 1, Kamila Cristina Oliveira (iD) 1, Marcia Helena Scabora (iD) 2, Barbara \\ Spessoto Martinez (iD) 3, Ricardo Dalla Villa (i] 3 \\ ${ }^{1}$ Federal Institute of Education, Science and Technology of Mato Grosso (IFMT), Campus Cuiabá - Bela Vista, Cuiabá, Mato \\ Grosso, Brazil. \\ ${ }^{2}$ Faculty of Technology (FATEC), Brazilian Industrial Apprenticeship Service (SENAI Mato Grosso), Cuiabá, Mato Grosso, \\ Brazil. \\ ${ }^{3}$ Department of Chemistry, Institute of Exact and Earth Sciences (ICET), Federal University of Mato Grosso (UFMT), \\ Campus Cuiabá (UFMT), Cuiabá, Mato Grosso, Brazil. \\ *Corresponding author. E-mail: adriana.oliveira@blv.ifmt.edu.br
}

\begin{abstract}
The aim of this work was to evaluate the physicochemical and microbiological properties of natural mineral waters bottled in 20 liter containers produced in Mato Grosso - Brazil. For this study, three lots of eight brands produced in the state and commercialized in Cuiabá were analyzed. The physicochemical parameters determined were $\mathrm{pH}$, electrical conductivity, total dissolved solids, total alkalinity, metals, ammonium, anions and glyphosate, and the measurements were made according to the Adolfo Lutz Institute and Standard Methods for the Examination of Water and Wastewater. Chromogenic enzymatic substrates were used to determine Coliform bacteria and filtration with a filtering membrane was used for the Pseudomonas aeruginosa count. The results were compared with national and international legislation on bottled water and the labeled values. All physicochemical parameters, except for $\mathrm{pH}$, showed concordant results with maximum values allowed by Brazilian and international law for the quality of bottled natural mineral waters. Six samples were investigated for the presence of coliforms and P. aeruginosa at $35{ }^{\circ} \mathrm{C}$. The results suggested possible contamination and failure during the industrialization process and the requirement for inspection during collection, manufacturing, labeling and commercialization of the natural mineral water bottled in 20 liter containers.
\end{abstract}

Keywords: Legislation, public health, trace elements, coliforms, Pseudomonas aeruginosa, Escherichia coli.

DOI: http://dx.doi.org/10.33837/msj.v3i1.1188

Received March 12, 2020. Accepted June 1, 2020.

Associate editor: Ana Paula Siqueira

\section{INTRODUCTION}

Water is an important chemical substance for the maintenance of life and its sanitary and rational use can impact the economy and public health. Water for human consumption must meet the potability standard for microbiological and physicochemical parameters and offer no risks to health (Chaplin, 2001, Adolfo Lutz Institute, 2008, Shahaby et al. 2015).

According to the Brazilian Legislation, natural mineral water is defined as that obtained directly from natural sources or groundwater extraction, and is characterized by a defined and constant content of certain minerals, trace elements and other constituents

\section{Copyright () The Author(s).}

This is an open-access paper published by the Instituto Federal Goiano,Urutai - GO, Brazil. All rights reserved. It is distributed under the terms of the Creative Commons Attribution 4.0 International License. considering natural fluctuations (Brazil, 2005).

The industrial process of filling and sealing containers with water is termed packaging and results in a product called bottled water, which is considered a food product and it is regulated by the Brazilian National Agency for Sanitary Surveillance (ANVISA) (Brazil 2005, Reis et al. 2014).

Global consumption of bottled natural mineral water has increased significantly in many countries, which can be attributed mainly to water scarcity, distrust of public water network quality, better taste than tap water, more affordable costs in recent years and the population's search for a healthy lifestyle and consumption of safe products (Cidu et al. 2011, FelipeSotelo et al. 2015).

According to the National Bureau of Brazilian Mineral Products (Brazil, 2017), Brazil is the world's fifth largest consumer of natural mineral water, with consumption of 20,848 million liters in 2016, and it has the nineteenth highest per capita consumption with 
101.2 liters per year. The Brazilian Association of the Mineral Water Industry (2017) reported a growth of $10 \%$ in the Brazilian market in recent years, with 20 liter bottles representing $55 \%$ of the Brazilian bottled mineral water market. The Mato Grosso state is the tenth biggest producer of Brazilian natural mineral water, with funding at a flow rate ranging between 8,000-1,500,000 L/h (ABINAM, 2017).

Water can serve as a vehicle for several biological and chemical agents, and the contamination of bottled natural mineral water can occur directly at the source, in the container (during the bottling process or as a result of reusing containers without properly sanitizing them), or during the transport and storage (Pontara et al. 2011, Abouleish, 2012, Cunha et al. 2012, Falcone-Dias et al. 2012, Moazeni et al. 2013, Inmetro, 2017).

Thus, the quality evaluation of natural mineral water bottled in this type of packaging becomes very important for public health (Santos et al. 2016), for the economy, and for the production of data that could assist in decisions and guidelines to control this product and the industry. Therefore, bottled water must be collected, processed and packaged respecting hygienic-sanitary conditions and good manufacturing practices.

Faced with the above, the aim of this work was to evaluate the physicochemical and microbiological quality of natural mineral waters bottled in 20 liter containers produced in the State of Mato Grosso, Brazil.

\section{MATERIAL AND METHODS}

Three lots of eight brands of natural mineral water bottled in 20 liter containers produced in the State of Mato Grosso were collected and identified by number. The lots were collected from September 2015 to April 2016 in commercial establishments randomly selected in Cuiabá city.

After collection, the 20 liter containers were sanitized externally with a neutral detergent, tap water and a $70 \%(\mathrm{v}: \mathrm{v})$ ethyl alcohol solution. At the time of the container opening, a new asepsis procedure was performed on the lid and bottleneck with a $70 \%(\mathrm{v}: \mathrm{v})$ ethyl alcohol solution (American Public Health Association, 1998).

High purity deionized water (resistivity 18.2 $\mathrm{M} \Omega \mathrm{cm}$, Milli-Q system, model Synergy, Millipore ${ }^{\circledR}$, Bedford, MA, USA) was used in the preparation of the standard solutions and samples. The reagents used in the determinations were of analytical grade.

The hydrogenionic potential $(\mathrm{pH})$, electrical conductivity and total dissolved solids were determined in triplicate by taking direct readings without prior sample preparation using a multiparameter probe mark Hanna ${ }^{\mathrm{TM}}$ (Texas, USA), hi 9828 model. The determination of total alkalinity was performed by the neutralization titration technique. All determinations were performed in triplicate according to the Adolfo Lutz Institute (Adolfo Lutz Institute 2008).

The wet decomposition was used as the sample preparation procedure (Toma \& Othman 2011) for determination of the concentrations of iron, zinc, copper, manganese, cadmium, chromium and lead with quantification by flame atomic absorption spectrometry (FAAS) using a SpectrAA 220 instrument (Varian ${ }^{\circledR}$ ) fitted with hollow cathode lamps. The aspiration rate of the working standard solutions or samples was adjusted to $2.00 \pm 0.2 \mathrm{~mL} / \mathrm{min}$. The measurements were carried out according to the manufacturer's recommendations.

The quantification of glyphosate, fluoride, chloride, nitrite, nitrate, bromide, phosphate and sulfate was made by liquid ion exchange chromatography in which the samples were initially filtered through a $0.48 \mu \mathrm{m}$ membrane. Chromatographic conditions were measured with a Metrohm ( chromatograph (Herisau, Switzerland), model 930 Compact IC Flex, 863 Sample Processor Campact, with Metrosep ASupp 7-250 / 4.0 column, Metrosep A Supp 16 guard / 4.0 column and detector 930 Compact IC Flex. Solutions of $10.8 \mathrm{mmol} / \mathrm{L}$ and $3.6 \mathrm{mmol} / \mathrm{L} \mathrm{Na} 2 \mathrm{CO} 3$ were used as the eluents for glyphosate and anion determinations, respectively, and a solution of $200 \mathrm{mmol} / \mathrm{L} \mathrm{H} 2 \mathrm{SO} 4$ was used as the regenerant. The flow rate was $0.8 \mathrm{~mL} / \mathrm{min}$ and the recording time was 35 minutes.

In the determination of the lithium, sodium, ammonium, potassium, calcium and magnesium contents, the samples were also filtered with a membrane of $0.48 \mu \mathrm{m}$ porosity and then quantified in a Metrohn(C) liquid ion exchange chromatograph (Herisau, Switzerland) model 882 Compact IC Plus, 863 Sample Processor Campact autosampler, with Metrosep C 4-150/4.0 column, pre-column Metrosep C4 (Guard/4.0). A mixed solution of nitric and dipicolinic acid with concentrations of 1.7 and 0.7 $\mathrm{mmol} / \mathrm{L}$, respectively, was used as the eluent with a flow rate of $0.9 \mathrm{~mL} / \mathrm{min}$ and a recording time of 25 $\min$.

The results obtained were compared with the legislation of the USA Food and Drug Administration Code of Federal Regulations 21, Resolution No. 274 of 22 September 2005 by Brazilian National Agency for Sanitary Surveillance, European Union, Commission Directive 2003/40 / EC, Ordinance No. 2914, of 12 December 2011 by the Brazilian National Agency for Sanitary Surveillance and labeled values (FDA 2015, Brazil 2005, Brazil 2011).

The results obtained in the physicochemical determinations were initially submitted to the Shapiro Wilk normality test and, if the data were not normally distributed, they were transformed using the logarithmic function $(\log 10 \mathrm{x})$. For the data that did 
not show normality even after data transformation, Friedman's non-parametric test was performed at 5\% of significance according to the recommendations of Helsen \& Hirsch (2012). The statistical treatment of the data was done using the ASSISTAT® version 7.7 beta program.

In the determination of coliform-type bacteria, chromogenic enzymatic substrate Petrifilms TM (3M TM Company, St. Paul, MN, USA) were used. For this, aliquots of $1.0 \mathrm{~mL}$ of the samples were inoculated and incubated at $35^{\circ} \mathrm{C}$ for $24 \mathrm{~h}$, and then at $45^{\circ} \mathrm{C}$ for $24 \mathrm{~h}$.

For Pseudomomas aeruginosa, a filtration process was performed using a filter holder previously sterilized with a filter membrane $(0.45 \mu \mathrm{m})$. After filtration of $100 \mathrm{~mL}$ of each sample, the filter membrane was transferred to the P. aeruginosa Petri dishes kit (Labor Clin $®$, Paraná, Brazil) and incubated at $35^{\circ} \mathrm{C}$ for approximately $24-48 \mathrm{~h}$. After this period, the typical colonies were counted (greenish coloration, with fluorescence).

The results obtained were compared with the Resolution No. 274 of 22 September 2005 by the Brazilian National Agency for Sanitary Surveillance (Brazil, 2005).

\section{RESULTS AND DISCUSSION}

The results obtained for the determination of the $\mathrm{pH}$, electrical conductivity, total dissolved solids, and total alkalinity are shown in the Table 1.

From the eight analyzed brands, only sample $\mathrm{H}$ presented $\mathrm{pH}$ values as recommended by Ordinance No. 2914 of 2011 by the Brazilian National Agency for Sanitary Surveillance (Brazil, 2011), and significant differences between lots of the same sample were verified, with the exception for the samples $C$ and $G$.

Table 1. Hydrogenionic potential $(\mathrm{pH})$, electrical conductivity (EC), total dissolved solids (TDS) and total alkalinity (mean \pm relative standard deviation $\%, n=3$ ) of natural mineral water bottled in 20 liter containers produced in Mato Grosso.

\begin{tabular}{|c|c|c|c|c|c|}
\hline Sample & Lot & $\mathrm{pH}$ & $\begin{array}{c}\mathrm{EC} \\
(\mu \mathrm{S} / \mathrm{cm})\end{array}$ & $\begin{array}{c}\text { TDS } \\
(\mathrm{mg} / \mathrm{L})\end{array}$ & $\begin{array}{l}\text { Total alkalinity } \\
\left(\mathrm{mg} \text { de } \mathrm{CaCO}_{3} / \mathrm{L}\right)\end{array}$ \\
\hline \multirow{3}{*}{ A } & 1 & $5.03 \pm 0.05^{a}$ & $15.00 \pm 0.57^{b}$ & $8.00 \pm 0.57^{b}$ & $12.64 \pm 0.00^{b}$ \\
\hline & 2 & $6.83 \pm 0.16^{b}$ & $14.00 \pm 0.57^{\mathrm{a} b}$ & $8.00 \pm 0.00^{b}$ & $6.32 \pm 0.00^{\mathrm{a}}$ \\
\hline & 3 & $5.78 \pm 0.05^{\mathrm{ab}}$ & $12.00 \pm 0.00^{a}$ & $4.00 \pm 0.00^{\mathrm{a}}$ & $7.90 \pm 0.00^{\mathrm{ab}}$ \\
\hline \multirow{3}{*}{ B } & 1 & $4.30 \pm 0.02^{\mathrm{a}}$ & $3.00 \pm 0.00^{\mathrm{a}}$ & $2.00 \pm 0.00^{b}$ & $3.16 \pm 0.00^{\mathrm{a}}$ \\
\hline & 2 & $6.13 \pm 0.18^{b}$ & $3.00 \pm 0.57^{a}$ & $2.00 \pm 0.00^{b}$ & $6.32 \pm 0.00^{\mathrm{a}}$ \\
\hline & 3 & $5.77 \pm 0.08^{\mathrm{ab}}$ & $2.00 \pm 0.00^{\mathrm{a}}$ & $1.00 \pm 0.00^{\mathrm{a}}$ & $6.32 \pm 0.00^{\mathrm{a}}$ \\
\hline \multirow{3}{*}{$\mathrm{C}$} & 1 & $5.23 \pm 0.08^{\mathrm{a}}$ & $24.00 \pm 0.57 \mathrm{ab}$ & $12.00 \pm 0.00^{\mathrm{ab}}$ & $20.01 \pm 1.82^{b}$ \\
\hline & 2 & $6.59 \pm 0.02^{\mathrm{a}}$ & $27.00 \pm 0.57 b$ & $14.00 \pm 0.00^{b}$ & $9.48 \pm 0.00^{\mathrm{a}}$ \\
\hline & 3 & $6.59 \pm 0.04^{\mathrm{a}}$ & $19.00 \pm 0.00^{a}$ & $4.00 \pm 0.00^{\mathrm{a}}$ & $14.22 \pm 0.00^{\mathrm{ab}}$ \\
\hline \multirow{3}{*}{$\mathrm{D}$} & 1 & $4.53 \pm 0.07 \mathrm{a}$ & $6.00 \pm 0.00^{\mathrm{ab}}$ & $3.00 \pm 0.00^{a}$ & $10.53 \pm 1.82^{\mathrm{a}}$ \\
\hline & 2 & $6.40 \pm 0.13^{b}$ & $7.00 \pm 0.57 \mathrm{~b}$ & $4.00 \pm 0.00^{\mathrm{b}}$ & $4.74 \pm 0.00^{\mathrm{a}}$ \\
\hline & 3 & $6.24 \pm 0.11^{\mathrm{ab}}$ & $5.00 \pm 0.00^{a}$ & $3.00 \pm 0.00^{\mathrm{a}}$ & $4.74 \pm 0.00^{a}$ \\
\hline \multirow{3}{*}{$\mathrm{E}$} & 1 & $4.37 \pm 0.04^{\mathrm{a}}$ & $4.00 \pm 0.00^{\mathrm{a}}$ & $2.00 \pm 0.00^{\mathrm{a}}$ & $5.27 \pm 1.82^{\mathrm{a}}$ \\
\hline & 2 & $5.94 \pm 0.09 \mathrm{ab}$ & $5.00 \pm 0.00^{\mathrm{a}}$ & $2.00 \pm 0.00^{a}$ & $6.32 \pm 0.00^{\mathrm{a}}$ \\
\hline & 3 & $6.08 \pm 0.02^{b}$ & $3.00 \pm 0.00^{\mathrm{a}}$ & $1.00 \pm 0.00^{\mathrm{a}}$ & $6.32 \pm 0.00^{\mathrm{a}}$ \\
\hline \multirow{3}{*}{$\mathrm{F}$} & 1 & $4.63 \pm 0.07 a$ & $36.00 \pm 0.57 \mathrm{ab}$ & $18.00 \pm 0.00^{\mathrm{ab}}$ & $7.37 \pm 1.82^{\mathrm{ab}}$ \\
\hline & 2 & $6.11 \pm 0.05^{\mathrm{b}}$ & $49.00 \pm 0.00^{\mathrm{b}}$ & $25.00 \pm 0.57^{b}$ & $6.32 \pm 0.00^{a}$ \\
\hline & 3 & $5.85 \pm 0.04^{\mathrm{ab}}$ & $23.00 \pm 0.57^{a}$ & $4.00 \pm 0.00^{a}$ & $7.90 \pm 0.00^{\mathrm{b}}$ \\
\hline \multirow{3}{*}{$\mathrm{G}$} & 1 & $4.25 \pm 0.05^{\mathrm{a}}$ & $4.00 \pm 0.00^{\mathrm{a}}$ & $2.00 \pm 0.00^{\mathrm{a}}$ & $6.32 \pm 0.00^{\mathrm{a}}$ \\
\hline & 2 & $5.68 \pm 0.12^{a}$ & $5.00 \pm 0.00^{a}$ & $3.00 \pm 0.00^{a}$ & $6.32 \pm 0.00^{a}$ \\
\hline & 3 & $5.66 \pm 0.06^{\mathrm{a}}$ & $4.00 \pm 0.57^{a}$ & $2.00 \pm 0.00^{\mathrm{a}}$ & $6.32 \pm 0.00^{\mathrm{a}}$ \\
\hline \multirow{3}{*}{$\mathrm{H}$} & 1 & $6.58 \pm 0.10^{a}$ & $148.00 \pm 0.00^{\mathrm{ab}}$ & $74.00 \pm 0.00^{\mathrm{ab}}$ & $112.71 \pm 1.82^{b}$ \\
\hline & 2 & $7.06 \pm 0.09 \mathrm{~b}$ & $153.00 \pm 0.00^{\mathrm{b}}$ & $77.00 \pm 0.57^{b}$ & $60.04 \pm 0.00^{\mathrm{a}}$ \\
\hline & 3 & $6.80 \pm 0.02^{\mathrm{ab}}$ & $128.00 \pm 2.00^{\mathrm{a}}$ & $4.00 \pm 0.00^{\mathrm{a}}$ & $61.62 \pm 0.00^{\mathrm{ab}}$ \\
\hline Brazil, 2011 & & $6.0-9.5$ & - & - & - \\
\hline FDA, 2015 & & - & - & 500 (Máx.) & - \\
\hline
\end{tabular}

The $\mathrm{pH}$ values below 6.0 can be attributed to the dissolution of rocks, absorption of gases from the atmosphere and photosynthetic processes. Aquifer recharge water is naturally acidic and this acidity is related to the dissociation of carbonic acid, produced by the dissolution of carbon dioxide, caused mainly by the degradation of organic matter and the respiration of roots. In general, the groundwater of shallow flow systems and rapid transit time in the aquifer has a higher acidity and a lower amount of dissolved solids, and the water with higher $\mathrm{pH}$ and greater amounts of dissolved solids are typical of deeper circulations, lower speeds and longer transit times (Cunha et al. 2012, Bortolo et al. 2007).

Baba et al. (2008) evaluated the quality of bottled mineral water in Turkey and all samples showed $\mathrm{pH}$ values below the level permitted by Turkish legislation (6.5-8.5). Neta, Leal and Reis (2013) evaluated the physicochemical and microbiological quality of mineral water commercialized in Teresina, 
Piauí, Brazil and, for the physicochemical parameters evaluated, only the $\mathrm{pH}$ showed a variation of values below the level allowed by the Brazilian Legislation.

All samples showed TDS values in accordance to those indicated by the FDA (2015) and significant differences between batches of the same sample were observed. The total alkalinity values quantified in the samples ranged from 3.16 to $112.71 \mathrm{mg} \mathrm{CaCO}_{3} / \mathrm{L}$ and significant differences between batches of the same sample were observed. For mineral water, there is no recommended value for this parameter described by ANVISA or FDA.

Astel et al. (2014) characterized forty-seven mineral water brands marketed in Zabrze and Słupsk in Poland and, in general, most of the parameters were below the guidelines of the World Health Organization, the European Union and the Polish Legislation. Among the parameters are the concentrations of ions and metals, $\mathrm{pH}$ and electrical conductivity.

The iron, copper, manganese, cadmium, chromium and lead levels showed concentrations below the instrumental detection limit. The zinc concentrations determined in the samples were in accordance to the maximum values allowed by ANVISA and FDA and significant differences were found between the zinc concentrations in lots of the same sample with the exception for the sample B, which can be attributed to the geochemical characteristics of the catchment region (Ikem et al. 2002). Morgano et al. (2002), evaluated the physicochemical quality of mineral water commercialized in Campinas, São Paulo, and the zinc content in the eight analyzed samples ranged from $\leq$ LDI to $0.03 \mathrm{mg} / \mathrm{L}$. The other metal species showed concentrations below the instrumental detection limit.

The fluoride, chloride, nitrate and sulfate concentrations (Table 2) were in accordance to the maximum values allowed by the European Union (2003), ANVISA (2001) and FDA (2015).

Significant differences were found between anion concentrations in lots of the same sample, which can also be attributed to local geochemical characteristics (Astel et al. 2014). The other anions presented concentrations lower than the limit of instrumental quantification.

Table 3 shows the results of the quantification of lithium, sodium, ammonium, potassium, calcium and magnesium cations concentration in natural mineral water samples. The ANVISA and FDA regulations have maximum permissible values for these ions in mineral water to which the sodium, potassium, calcium, and manganese are added intentionally, but do not have maximum permissible values for natural mineral water.

Table 2. Concentration of fluoride, chloride, nitrate and sulfate (mean \pm relative standard deviation $\%, n=3$ ) of natural mineral water bottled in 20 liter containers produced in Mato Grosso.

\begin{tabular}{|c|c|c|c|c|c|}
\hline \multirow{2}{*}{ Sample } & \multirow{2}{*}{ Lot } & $\mathrm{F}^{-}$ & $\mathrm{Cl}^{-}$ & $\mathrm{NO}_{3}^{-}$ & $\mathrm{SO}_{4}{ }^{2-}$ \\
\hline & & \multicolumn{4}{|c|}{$\mathrm{mg} \mathrm{L}^{-1}$} \\
\hline \multirow{3}{*}{ A } & 1 & $0.029 \pm 0.00^{a}$ & $0.099 \pm 0.00^{\mathrm{b}}$ & $\leq \mathrm{LDI}$ & $0.759 \pm 0.00^{a}$ \\
\hline & 2 & $0.031 \pm 0.00^{\mathrm{ab}}$ & $0.070 \pm 0.00^{\mathrm{a}}$ & $\leq \mathrm{LDI}$ & $0.785 \pm 0.00^{\mathrm{ab}}$ \\
\hline & 3 & $0.031 \pm 0.00^{\mathrm{ab}}$ & $0.080 \pm 0.00^{\mathrm{ab}}$ & $\leq$ LDI & $0.791 \pm 0.00^{\mathrm{b}}$ \\
\hline \multirow{3}{*}{ B } & 1 & $\leq \mathrm{LDI}$ & $\leq \mathrm{LDI}$ & $0.159 \pm 0.00^{b}$ & $0.135 \pm 0.00^{b}$ \\
\hline & 2 & $\leq \mathrm{LDI}$ & $\leq \mathrm{LDI}$ & $0.157 \pm 0.00^{\mathrm{ab}}$ & $0.110 \pm 0.00^{\mathrm{ab}}$ \\
\hline & 3 & $\leq \mathrm{LDI}$ & $\leq \mathrm{LDI}$ & $0.027 \pm 0.00^{\mathrm{a}}$ & $0.089 \pm 0.00^{a}$ \\
\hline \multirow{3}{*}{$\mathrm{C}$} & 1 & $\leq \mathrm{LDI}$ & $\leq \mathrm{LDI}$ & $0.157 \pm 0.00^{\mathrm{b}}$ & $0.176 \pm 0.00^{\mathrm{ab}}$ \\
\hline & 2 & $\leq \mathrm{LDI}$ & $\leq \mathrm{LDI}$ & $0.149 \pm 0.00^{\mathrm{ab}}$ & $0.173 \pm 0.00^{a}$ \\
\hline & 3 & $\leq \mathrm{LDI}$ & $\leq \mathrm{LDI}$ & $0.027 \pm 0.00^{a}$ & $0.180 \pm 0.00^{\mathrm{b}}$ \\
\hline \multirow{3}{*}{$\mathrm{D}$} & 1 & $0.008 \pm 0.00^{\mathrm{ab}}$ & $0.107 \pm 0.00^{\mathrm{b}}$ & $0.990 \pm 0.00^{\mathrm{b}}$ & $0.109 \pm 0.00^{b}$ \\
\hline & 2 & $0.010 \pm 0.00^{\mathrm{b}}$ & $0.056 \pm 0.00^{\mathrm{a}}$ & $0.958 \pm 0.00^{\mathrm{ab}}$ & $0.099 \pm 0.00^{\mathrm{ab}}$ \\
\hline & 3 & $0.004 \pm 0.00^{a}$ & $0.070 \pm 0.00^{\mathrm{ab}}$ & $0.917 \pm 0.00^{\mathrm{a}}$ & $0.072 \pm 0.00^{\mathrm{a}}$ \\
\hline \multirow{3}{*}{$\mathrm{E}$} & 1 & $\leq \mathrm{LDI}$ & $0.114 \pm 0.00^{\mathrm{b}}$ & $0.244 \pm 0.00^{\mathrm{ab}}$ & $0.120 \pm 0.00^{\mathrm{b}}$ \\
\hline & 2 & $\leq \mathrm{LDI}$ & $0.075 \pm 0.00^{a}$ & $0.251 \pm 0.00^{b}$ & $0.103 \pm 0.00^{\mathrm{ab}}$ \\
\hline & 3 & $\leq \mathrm{LDI}$ & $0.094 \pm 0.00^{\mathrm{ab}}$ & $0.161 \pm 0.00^{a}$ & $0.077 \pm 0.00^{a}$ \\
\hline \multirow{3}{*}{ F } & 1 & $\leq \mathrm{LDI}$ & $2.605 \pm 0.00^{\mathrm{ab}}$ & $9.722 \pm 0.00^{\mathrm{ab}}$ & $0.130 \pm 0.00^{b}$ \\
\hline & 2 & $\leq \mathrm{LDI}$ & $3.475 \pm 0.00^{\mathrm{b}}$ & $13.463 \pm 0.00^{\mathrm{b}}$ & $0.107 \pm 0.00^{\mathrm{ab}}$ \\
\hline & 3 & $\leq \mathrm{LDI}$ & $1.930 \pm 0.00^{a}$ & $8.043 \pm 0.00^{a}$ & $0.082 \pm 0.00^{a}$ \\
\hline \multirow{3}{*}{ G } & 1 & $\leq \mathrm{LDI}$ & $0.104 \pm 0.00^{\mathrm{ab}}$ & $0.292 \pm 0.00^{a}$ & $0.104 \pm 0.00^{\mathrm{ab}}$ \\
\hline & 2 & $\leq \mathrm{LDI}$ & $0.071 \pm 0.00^{a}$ & $0.304 \pm 0.00^{\mathrm{b}}$ & $0.099 \pm 0.00^{a}$ \\
\hline & 3 & $\leq \mathrm{LDI}$ & $0.138 \pm 0.00^{\mathrm{b}}$ & $0.302 \pm 0.00^{\mathrm{ab}}$ & $0.119 \pm 0.00^{\mathrm{b}}$ \\
\hline \multirow{3}{*}{$\mathrm{H}$} & 1 & $0.056 \pm 0.00^{\mathrm{ab}}$ & $3.547 \pm 0.00^{\mathrm{b}}$ & $1.337 \pm 0.00^{\mathrm{b}}$ & $0.706 \pm 0.00^{a}$ \\
\hline & 2 & $0.055 \pm 0.00^{a}$ & $3.322 \pm 0.00^{\mathrm{ab}}$ & $1.201 \pm 0.00^{\mathrm{ab}}$ & $0.762 \pm 0.00^{\mathrm{ab}}$ \\
\hline & 3 & $0.061 \pm 0.00^{\mathrm{b}}$ & $2.787 \pm 0.00^{a}$ & $0.698 \pm 0.00^{a}$ & $6.267 \pm 0.00^{\mathrm{b}}$ \\
\hline MTL & & $5^{\dagger}$ & $250+t$ & $50^{\dagger}$ & $250+t$ \\
\hline
\end{tabular}

MTL = Maximum tolerable limit. LDI = instrumental limit of detection. ${ }^{\dagger}$ Brazil, 2011. ${ }^{\dagger+F D A, ~ 2015 . ~}{ }^{\text {a,b }}$ Values followed by the same letter in the same column indicate no significant difference between the lots at the $5 \%$ confidence level. 
Table 3. Concentration of lithium, sodium, potassium, calcium and magnesium ions (mean \pm relative standard deviation $\%$, $\mathrm{n}=3$ ) of natural mineral water bottled in 20 liter containers produced in Mato Grosso.

\begin{tabular}{|c|c|c|c|c|c|c|}
\hline \multirow[b]{2}{*}{ Sample } & \multirow[b]{2}{*}{ Lot } & $\mathrm{Li}^{+}$ & $\mathrm{Na}^{+}$ & $\mathbf{K}^{+}$ & $\mathrm{Ca}^{2+}$ & $\mathrm{Mg}^{2+}$ \\
\hline & & \multicolumn{5}{|c|}{$\mathrm{mg} / \mathrm{L}$} \\
\hline \multirow{3}{*}{ A } & 1 & $0.002 \pm 0.00^{a}$ & $0.468 \pm 0,00^{a}$ & $1.735 \pm 0.00^{a}$ & $0.671 \pm 0.00^{b}$ & $0.545 \pm 0.00^{\mathrm{ab}}$ \\
\hline & 2 & $0.002 \pm 0.00^{\mathrm{a}}$ & $0.468 \pm 0,00^{a}$ & $1.753 \pm 0.00^{a}$ & $0.532 \pm 0.00^{\mathrm{ab}}$ & $0.557 \pm 0.00^{b}$ \\
\hline & 3 & $0.002 \pm 0.00^{a}$ & $0.635 \pm 0,00^{\mathrm{a}}$ & $1.820 \pm 0.00^{\mathrm{a}}$ & $0.224 \pm 0.00^{\mathrm{a}}$ & $0.462 \pm 0.00^{a}$ \\
\hline \multirow{3}{*}{ B } & 1 & $\leq \mathrm{LDI}$ & $0.011 \pm 0,00^{\mathrm{ab}}$ & $0.069 \pm 0.00^{\mathrm{ab}}$ & $\leq \mathrm{LDI}$ & $0.062 \pm 0.00^{\mathrm{b}}$ \\
\hline & 2 & $\leq \mathrm{LDI}$ & $0.012 \pm 0,00^{\mathrm{b}}$ & $0.077 \pm 0.00^{\mathrm{b}}$ & $\leq \mathrm{LDI}$ & $0.060 \pm 0.00^{\mathrm{ab}}$ \\
\hline & 3 & $\leq \mathrm{LDI}$ & $0.006 \pm 0,00^{\mathrm{a}}$ & $0.040 \pm 0.00^{\mathrm{a}}$ & $\leq \mathrm{LDI}$ & $0.005 \pm 0.00^{\mathrm{a}}$ \\
\hline \multirow{3}{*}{$\mathrm{C}$} & 1 & $0.003 \pm 0.00^{a}$ & $1.269 \pm 0,00^{\mathrm{ab}}$ & $2.326 \pm 0.00^{\mathrm{b}}$ & $0.901 \pm 0.00^{\mathrm{a}}$ & $1.159 \pm 0.00^{\mathrm{ab}}$ \\
\hline & 2 & $0.003 \pm 0.00^{\mathrm{a}}$ & $1.224 \pm 0,00^{\mathrm{a}}$ & $1.166 \pm 0.00^{\mathrm{a}}$ & $1.122 \pm 0.00^{\mathrm{b}}$ & $1.141 \pm 0.00^{a}$ \\
\hline & 3 & $0.004 \pm 0.00^{\mathrm{a}}$ & $1.382 \pm 0,00^{\mathrm{b}}$ & $2.268 \pm 0.00^{\mathrm{ab}}$ & $0.933 \pm 0.00^{\mathrm{ab}}$ & $1.187 \pm 0.00^{\mathrm{b}}$ \\
\hline \multirow{3}{*}{$\mathrm{D}$} & 1 & $\leq \mathrm{LDI}$ & $0.048 \pm 0,00^{\mathrm{a}}$ & $0.714 \pm 0.00^{\mathrm{ab}}$ & $\leq \mathrm{LDI}$ & $0.153 \pm 0.00^{b}$ \\
\hline & 2 & $\leq \mathrm{LDI}$ & $0.052 \pm 0,00^{\mathrm{ab}}$ & $0.715 \pm 0.00^{\mathrm{b}}$ & $\leq \mathrm{LDI}$ & $0.150 \pm 0.00^{a b}$ \\
\hline & 3 & $\leq \mathrm{LDI}$ & $0.105 \pm 0,00^{\mathrm{b}}$ & $0.713 \pm 0.00^{\mathrm{a}}$ & $\leq \mathrm{LDI}$ & $0.061 \pm 0.00^{a}$ \\
\hline \multirow{3}{*}{$\mathrm{E}$} & 1 & $\leq \mathrm{LDI}$ & $0.061 \pm 0,00^{\mathrm{ab}}$ & $0.292 \pm 0.00^{\mathrm{ab}}$ & $\leq \mathrm{LDI}$ & $0.052 \pm 0.00^{\mathrm{b}}$ \\
\hline & 2 & $\leq \mathrm{LDI}$ & $0.056 \pm 0,00^{a}$ & $0.305 \pm 0.00^{\mathrm{b}}$ & $\leq \mathrm{LDI}$ & $0.049 \pm 0.00^{\mathrm{ab}}$ \\
\hline & 3 & $\leq \mathrm{LDI}$ & $0.113 \pm 0,00^{\mathrm{b}}$ & $0.284 \pm 0.00^{a}$ & $\leq \mathrm{LDI}$ & $0.016 \pm 0.00^{a}$ \\
\hline \multirow{3}{*}{$\mathrm{F}$} & 1 & $\leq \mathrm{LDI}$ & $4.906 \pm 0,00^{\mathrm{b}}$ & $1.047 \pm 0.00^{\mathrm{ab}}$ & $0.302 \pm 0.00^{\mathrm{ab}}$ & $0.122 \pm 0.00^{\mathrm{ab}}$ \\
\hline & 2 & $\leq \mathrm{LDI}$ & $0.011 \pm 0,00^{a}$ & $1.421 \pm 0.00^{\mathrm{b}}$ & $0.614 \pm 0.00^{\mathrm{b}}$ & $0.181 \pm 0.00^{b}$ \\
\hline & 3 & $\leq \mathrm{LDI}$ & $4.595 \pm 0,00^{\mathrm{ab}}$ & $0.644 \pm 0.00^{\mathrm{a}}$ & $0.063 \pm 0.00^{\mathrm{a}}$ & $0.051 \pm 0.00^{a}$ \\
\hline \multirow{3}{*}{ G } & 1 & $\leq \mathrm{LDI}$ & $0.023 \pm 0,00^{\mathrm{ab}}$ & $0.264 \pm 0.00^{\mathrm{ab}}$ & $\leq \mathrm{LDI}$ & $0.038 \pm 0.00^{\mathrm{ab}}$ \\
\hline & 2 & $\leq \mathrm{LDI}$ & $0.039 \pm 0,00^{\mathrm{b}}$ & $0.302 \pm 0.00^{\mathrm{b}}$ & $\leq \mathrm{LDI}$ & $0.049 \pm 0.00^{\mathrm{b}}$ \\
\hline & 3 & $\leq \mathrm{LDI}$ & $0.008 \pm 0,00^{a}$ & $0.251 \pm 0.00^{a}$ & $\leq \mathrm{LDI}$ & $0.010 \pm 0.00^{a}$ \\
\hline \multirow{3}{*}{$\mathrm{H}$} & 1 & $0.014 \pm 0.00^{\mathrm{a}}$ & $6.403 \pm 0,00^{\mathrm{ab}}$ & $0.896 \pm 0.00^{\mathrm{ab}}$ & $2.035 \pm 0.00^{\mathrm{ab}}$ & $5.311 \pm 0.00^{\mathrm{ab}}$ \\
\hline & 2 & $0.014 \pm 0.00^{\mathrm{a}}$ & $0.140 \pm 0,00^{\mathrm{a}}$ & $0.913 \pm 0.00^{\mathrm{b}}$ & $1.918 \pm 0.00^{\mathrm{a}}$ & $4.964 \pm 0.00^{\mathrm{a}}$ \\
\hline & 3 & $0.017 \pm 0.00^{\mathrm{a}}$ & $9.223 \pm 0,00^{\mathrm{b}}$ & $0.876 \pm 0.00^{\mathrm{a}}$ & $29.929 \pm 0.00^{b}$ & $6.073 \pm 0.00^{\mathrm{ab}}$ \\
\hline
\end{tabular}

LDI $=$ instrumental limit of detection. $\mathrm{a}, \mathrm{b}$ Values followed by the same letter in the same column indicate no significant difference between the lots at the $5 \%$ confidence level.

Significant differences were found between sodium, potassium, calcium, and manganese concentrations in batches of the same sample. Morgano et al. (2002) also found different concentrations of sodium (0.53-97.29 mg/L), potassium (0.39-3.27 mg/L), calcium (0.53-28.35 $\mathrm{mg} / \mathrm{L}$ ) and magnesium (0.00-9.10 mg/L) in eight mineral waters commercialized in the city of Campinas, which reinforces that local geochemical characteristics may be related to the concentration of trace elements in natural mineral waters.

Sample $\mathrm{H}$ presented a lithium content above $0.01 \mathrm{mg} / \mathrm{L}$ and, according to Ordinance No. 540 of December 18, 2014 of the Brazilian Mineral Production Department (Brazil, 2014), natural mineral water with lithium concentrations of at least $0.01 \mathrm{mg} / \mathrm{L}$ can be classified as lithia mineral water. Studies indicate that the ingestion of low lithium concentrations present in mineral water may increase serum lithium levels and improve mood in humans (Zawisza \& Sitko, 2011).

The main sources of natural mineral water in the Mato Grosso State are located in regions of large agricultural production where the use of agrochemical glyphosate is made on a large scale. Therefore, it is important to quantify this analyte in all samples. All the mineral water samples analyzed in the three different lots presented glyphosate concentrations below the instrument detection limit $(5.0 \mu \mathrm{g} / \mathrm{L})$, and met the maximum value allowed by the Brazilian legislation for bottled water quality, which is 500 $\mu \mathrm{g} / \mathrm{L}$.

Table 4 shows the results obtained to coliform type bacterium and Pseudomonas aeruginosa counts in the natural mineral water samples evaluated in this study $\left(\mathrm{CFU} \mathrm{mL} \mathrm{m}^{-1}\right)$.

The results indicated that from 24 analyzed samples, six showed the presence of Pseudomonas aeruginosa. Farache Filho and Dias (2008) evaluated microbiological parameters of natural mineral water bottles bottled in 20 liter containers of different brands marketed in the Araraquara and Américo Brasiliense cities of São Paulo, Brazil, and eight samples (9.5\%) of six brands $(28.6 \%)$ were non-standard for $P$. aeruginosa. Al Hazzani et al. (2013) evaluated the presence of Pseudomonas aeruginosa in 20 samples of natural mineral waters bottled in Saudi Arabia, and $60 \%$ of the samples showed the presence of the microorganism. Reis et al. (2014) detected the presence of Pseudomonas aeruginosa in samples of natural mineral water bottled in 20 liter containers produced in Viçosa, Minas Gerais, Brazil. 
Table 4. Results (UFC mL-1) for microbiological analyses of Coliformes $35^{\circ} \mathrm{C}$, Coliformes $45^{\circ} \mathrm{C}$, Escherichia coli and Pseudomonas aeruginosa of natural mineral water bottled in 20 liter containers produced in Mato Grosso.

\begin{tabular}{|c|c|c|c|c|c|c|c|c|c|}
\hline \multirow{2}{*}{ Sample } & \multicolumn{3}{|c|}{ Coliformes $35^{\circ} \mathrm{C}$} & \multicolumn{3}{|c|}{ Coliformes $45^{\circ} \mathrm{C}$ and Escherichia coli } & \multicolumn{3}{|c|}{ Pseudomonas aeruginosa } \\
\hline & $1^{\circ}$ lot & $2^{\circ}$ lot & $3^{\circ}$ lot & $1^{\circ}$ lot & $2^{\circ}$ lot & $3^{\circ}$ lot & $1^{\circ}$ lot & $2^{\circ}$ lot & $3^{\circ}$ lot \\
\hline A & 0 & 0 & $>300$ & 0 & 0 & 0 & 0 & 0 & 0 \\
\hline $\mathrm{B}$ & 0 & 0 & $1.6 \times 10^{2}$ & 0 & 0 & 0 & 0 & 0 & 0 \\
\hline $\mathrm{C}$ & 0 & 0 & $2.6 \times 10^{1}$ & 0 & 0 & 0 & 0 & 0 & 0 \\
\hline $\mathrm{D}$ & 0 & 0 & $2.4 \times 10^{2}$ & 0 & 0 & 0 & 0 & $8.0 \times 10^{1}$ & 0 \\
\hline $\mathrm{E}$ & 0 & 0 & $2.6 \times 10^{2}$ & 0 & 0 & 0 & 0 & 0 & 0 \\
\hline $\mathrm{F}$ & 0 & 0 & 0 & 0 & 0 & 0 & $7.0 \times 10^{1}$ & $4.0 \times 10^{1}$ & 0 \\
\hline G & 0 & 0 & 0 & 0 & 0 & 0 & 0 & 0 & 0 \\
\hline $\mathrm{H}$ & 0 & 0 & $5.3 \times 10^{2}$ & 0 & 0 & 0 & 0 & 0 & 0 \\
\hline
\end{tabular}

Pseudomonas are a large group of free-living bacteria that live mainly on soil, sea water and freshwater, colonize plants and animals, and are often found in domestic and clinical environments. In humans, they are responsible for ocular and cutaneous diseases and can cause serious fatal illnesses in burned and surgical patients and in immunocompromised individuals (Mena \& Gerba 2009). According to Coelho et al. (2010), Pseudomonas aeruginosa became a commonplace bacteria in microbiological analyses in chlorinated, non-chlorinated and natural mineral water in Brazil.

In the samples from this study, the presence of coliforms was observed in six samples $(25 \%)$, in the third collection at $35^{\circ} \mathrm{C}$ and the presence of coliforms, including Escherichia coli, was not observed in any collection at $45^{\circ} \mathrm{C}$ (Table 4). The difference between the coliform counts at $35^{\circ} \mathrm{C}$ obtained in the third collection with the others can be explained due to the presence of Pseudomonas aeruginosa in the sample. According to Coelho et al. (2010), Pseudomonas aeruginosa inhibits the growth of bacteria in the coliform group, i.e., this bacteriostatic effect contributed to the presence of this bacterium only in the third collection.

The positive results for coliforms at $35^{\circ} \mathrm{C}$ suggest possible failures during the industrialization process. Zan et al. (2013) evaluated the microbiological content of mineral water commercialized in the Region of Vale do Jamari, Rondônia, Brazil, and the results indicated that contamination with bacteria of the coliform group at $35^{\circ} \mathrm{C}$ was found in all batches analyzed, and in some cases, the presence of E. coli was also found. Zago et al. (2013) analyzed the microbiological content of bottled natural mineral water sold in Tangará da Serra city, Mato Grosso, Brazil and two samples $(4.8 \%)$ presented coliform counts at $35^{\circ} \mathrm{C}$, being one sample $(2.4 \%)$ was not according to Brazilian Legislation. Shahaby et al. (2015) detected the presence of coliform bacteria in bottled natural mineral water samples in the Taif region, Saudi Arabia.

\section{CONCLUSION}

All physicochemical parameters except for $\mathrm{pH}$ showed concordant results with maximum values allowed by Brazilian and international law quality of bottled natural mineral waters. In the case of $\mathrm{pH}$, the results obtained were lower than those allowed by the legislation, which can be attributed to the influence of groundwater circulation depth and rock dissolution. In addition, significant differences were observed between the results obtained in the samples between the three lots, which can be attributed to the geological patterns of the catchment areas. For all samples, the absence of coliforms and Escherichia coli was verified at $45{ }^{\circ} \mathrm{C}$, but six samples showed the presence of $P$. aeruginosa and coliforms at $35{ }^{\circ} \mathrm{C}$, suggesting possible contaminations and failures during the industrialization process.

The results obtained in this work demonstrate the importance of compliance with Good Manufacturing Practices and the need for greater monitoring and inspection of natural mineral water bottled in 20 liter containers, during collection, manufacturing, labeling and commercialization.

\section{CONFLICT OF INTEREST}

None to declare.

\section{ACKNOWLEDGEMENTS}

The authors thanks to the Brazilian Coordination for the Improvement of Higher Education Personnel (CAPES) and Brazilian National Council for Scientific and Technological Development (CNPq) and for providing scholarships to I.C.T.R and K.C.O., respectively. The authors also thank $3 \mathrm{M} \otimes$ of the Brazil for the award of the work in the Cultivating Talents Award and Laborclin.

\section{REFERENCES}

Abouleish, M. Y. Z. (2012). Concentration of selected anions in bottled water in the United Arab Emirates. International Journal Environmental Research Public Health, 4, 496-509.

Al Hazzani, A. A., Al Farra, L. W., Asran, A., Sherata, A. I. \& Moubayed, N. M. S. (2013). Bacterial quality control of 
domestic and imported brands of bottled water in Saudi Arabia. Journal of Toxicology Environmental Health Science, 5 (10), 178-184.

Astel, A., Michalski, R., Lyko, A., Jablonska-Czapla, M., Bigus, K., Szopa, S. \& Kwieciska, A. (2014). Characterization of bottled mineral waters marketed in Poland using hierarchical cluster analysis. Journal of Geochemical Exploration, 143, 136-145.

Baba, A., Ereeş, F. S., Hıçsönmez, Ü., Çam, S. \& Özdılek, H. G. (2008). An assessment of the quality of various bottled mineral water marketed in Turkey. Environmental Monitoring Assessement, 139, 277-285.

Bortolo, R., Hirata, R. \& Fernandes, A. (2007). Hidrogeoquímica das águas minerais envasadas do Brasil (Hydrogeochemistry of the bottled mineral waters of Brazil). Brazilian Journal of Geology ,37 (3), 515-529.

Brazil, Brazilian Association of Mineral Water Industries (ABINAM). (2017). O mercado de 7 bi de litros. http://www.abinam.com.br/lermais_materias.php?cd_materi as=71 (accessed 14 May 2019).

Brazil, Brazilian Mineral Production Department . (2014). Ordinance no. 540 of 18 December 2014 http://www.dnpm.gov.br/acesso-ainformacao/legislacao/portarias-do-diretor-geral-do$\mathrm{dnpm} /$ portarias-do-diretor-geral/portaria-no-540-em-18-122014-do-diretor-geral-do-dnpm (accessed 14 May 2019).

Brazil, Brazilian Mineral Production Department, Mineral Summary. (2017). http://www.anm.gov.br/dnpm/publicacoes/serieestatisticas-e-economia-mineral/sumariomineral/agua_mineral_sm_2017 (accessed 14 May 2019).

Brazil, Brazilian National Agency for Sanitary Surveillance. (2005). Resolution No. 274 of 22 September 2005. http://www.saude.rj.gov.br/comum/code/MostrarArquivo. php?C=MTk3NA\%2C\%2C (accessed 14 May 2019).

Brazil, Brazilian National Agency for Sanitary Surveillance. (2011). Ordinance No. 2914 of 12 December. 2011. http://bvsms.saude.gov.br/bvs/saudelegis/gm/2011/prt291 4_12_12_2011.html (accessed 14 May 2019).

Brazil, Brazilian National Agency for Sanitary Surveillance. (2005). Resolution No. 274 of 22 September 2005. http://www.saude.rj.gov.br/comum/code/MostrarArquivo. php?C $=$ MTk3Ng\%2C\%2C (accessed 14 May 2019).

Chaplin, M. F. (2001). Water: it's important to life. Biochemistry Molecular Biology Education, 29, 54-59.

Cidu, R., Frau, F. \& Tore, P. (2011). Drinking water quality: comparing inorganic components in bottled water and Italian tap water. Journal Food Composition and Analysis, 24 (2), 184193.

Coelho, M. I. S., Mendes, E. S., Cruz, M. C. S., Bezerra, S. S. \& Silva, R. P. P. (2010). Avaliação da qualidade microbiológica de águas minerais consumidas na região metropolitana de Recife, Estado de Pernambuco. Acta Scientarium Health Science, 32 (1), $1-8$.

Cunha, H. F. A., Lima, D. C. I., Brito, P. N. F., Cunha, A. C., Silveira Junior, A. M. \& Brito, D. C. (2012). Qualidade físico-química e microbiológica de água mineral e padrões da legislação (Physicochemical and microbiological quality of mineral water and the legislation standards). Revista Ambiente E Água - An Interdisciplinary Journal of Applied Science 7 (3), 155-165.

European Union, Commission Directive 2003/40/EC. (2003). Establishing the list, concentration limits and labelling requirements for the constituents of natural mineral waters and the conditions for using ozone-enriched air for the treatment of natural mineral waters and spring waters. http://eur-lex.europa.eu/eli/dir/2003/40/oj (accessed 14 May 2019).

Falcone-Dias M. F., Vaz-Moreira, I. \& Manaia, C. F. (2012). Bottled mineral water as a potential source of antibiotic resistant bacteria. Water Research, 46, 3612-3622.

Farache Filho, A. \& Dias, M. F. F. (2008). Qualidade microbiológica de águas minerais em galões de 20 litros (Microbiological quality of mineral waters in gallons of 20 liters). Brazilian Journal of Food and Nutrition, 19 (3), 243-248.

FDA, U. S. Food and Drug Administration. (2015). CFR - Code of

\section{Federal}

Regulations

Title

21.

http://www.accessdata.fda.gov/scripts/cdrh/cfdocs/cfcfr/cf rsearch.cfm?fr=165 (accessed 14 May 2019).

Felipe-Sotelo, M., Henshall-Bell, E. R., Evans, N. D. M. \& Read, D. (2015). Comparison of the chemical composition of British and Continental European bottled waters by multivariate analysis. Journal Food Composition and Analysis, 39, 33-42.

Helsen, D. R. \& Hirsch R. M. (2012). Statistical Methods in Water Resources. USGS: New York, USA.

Ikem, A., Odueyungbo, S., Egiebor, N. O. \& Nyavor K. (2002). Chemical quality of bottled waters from three cities in eastern Alabama. Science and Total Environment, 285, 165-175.

Mena. K. \& Gerba, C. (2009). Risk Assessment of Pseudomonas Aeruginosa in Water. Reviews Environmental Contamination Toxicology, 201, 71-115.

Moazeni, M., Atefi, M., Ebrahimi, A., Razmjoo, P. \& Vahid Dastjerdi, M. (2013). Evaluation of Chemical and Microbiological Quality in 21 Brands of Iranian Bottled Drinking Waters in 2012: A Comparison Study on Label and Real Contents. Journal of Environmental and Public Health, 1, 1-4.

Morgano, M. A., Schatti, A. C., Eriques, H. A. \& Mantovani, D. M. B. (2002). Physical-chemical evaluation of mineral waters marketed in Campinas, SP. Food Science and Technology, 22 (3), 239-243.

National Institute of Metrology, Standardization and Industrial Quality (INMETRO). ( 2017). Água mineral em garrafões de 20 $\mathrm{L}$ (Mineral water in $20 \mathrm{~L}$ bottles). http://www.inmetro.gov.br/consumidor/produtos/garrafoe s.asp (accessed 14 May 2019).

Neta, M. S. B., Leal, M. P. N. \& Reis, A. S. (2013). Análise físicoquímica, microbiológica de água mineral produzida no nordeste e comercializada em Teresina - Piauí (Physicochemical and microbiological analysis of mineral water produced in the northeast and commercialized in Teresina Piauí). Revista Interdisicplinar, 6(2), 33-37.

Normas Analíticas do Instituto Adolfo Lutz: Métodos químicos e físicos para análise de alimentos. (2008). 1st edn. Adolfo Lutz Institute, IAL, São Paulo, BR.

Pontara, A. V., Oliveira, C. D. D., Barbosa, A. H., Santos, R. A., Pires, R. H. \& Martins, C. H. G. (2011). Microbiological monitoring of mineral water commercialized in Brazil. Brazilian Journal of Microbiology, 42(2), 554-559.

Reis, R. L., Bevilacqua, P. D. \& Carmo, R. F. (2014). Água envasada: qualidade microbiológica e percepção dos consumidores no município de Viçosa (MG) (Bottled water: microbiological quality and consumer perception in Viçosa (MG)). Caderno de Saúde Coletiva, 22 (3), 224-232.

Santos, E. J., Oliveira Junior, D. R., Hermann, A. B. \& Sturgeon R. E. (2016). Chemical quality of bottled mineral waters from markets of Curitiba-PR-Brazil. Brazilian Archives of Biology Technology, 59, 1-13.

Shahaby, A. F., Alharthi, A. A. \& El Tarras, A. E. (2015). Bacteriological evaluation of tap water and bottled mineral water in Taif, Western Saudi Arabia. International Journal of Current Microbiology and Applied Sciences 4 (12), 600-615.

Standard Methods for the Examination of Water and Wastewater. (1998). 20th edn, American Public Health Association/American Water Works Association/Water Environment Federation, Washington DC, USA

Toma, J. J. \& Othman, M. A. (2011). Determination of the trace metals in bottled water that are available in Erbil City, Iraq. Journal Environmental Studies [JES] 6, 31-37.

Zago, B. W., Carvalho, I. F. \& Carvalho, M. L. S. (2013). Qualidade bacteriológica de água mineral comercializada em Tangará da Serra - MT (Bacteriological quality of mineral water commercialized in Tangará da Serra - MT). Brazilian Journal of Food and Nutrition, 24 (3), 311-315.

Zan, R. A., Vieira, F. G., Bavaresco, M. F. \& Meneghetti, D. U. O. (2013). Avaliação da qualidade de águas minerais comercializadas nas cidades do vale do Jamari, Amazônia Ocidental, Rondônia - Brasil (Quality assessment of mineral waters in cities of commercially Jamari valley, Western Amazon, Rondônia-Brazil). Revista Saúde Pública Santa 
Catarina, 6 (4), 19-26

Zawisza, B. \& Sitko, R. (2011). Determination of lithium in mineral water samples by X-Ray Fluorescence Spectrometry. Applied Spectrometry, 65 (10), 1218-1221.

To cite this paper:

Ribeiro, I., Oliveira, A., David, A., Oliveira, K., Scabora, M., Martinez, B., Villa, R. (2020). Physicochemical and microbiological evaluation of natural mineral water produced in Mato Grosso State, Brazil. Multi-Science Journal, 3(1): 32-39. DOI: http://dx.doi.org/10.33837/msj.v3i1.1188 